\title{
DINAMIKA PROSES PENCALONAN ANGGOTA DPRD KABUPATEN SOLOK UNTUK PEMILU SERENTAK TAHUN 2019
}

\author{
Viko Darma 1), Nursyirwan Effendi ${ }^{2)}$, Khairul Fahmi ${ }^{3)}$ \\ 1,2,3) Megister Kosentrasi Tata Kelola Pemilu Fakultas Ilmu Sosial Dan Ilmu Politik \\ Universitas Andalas, Padang, Indonesia
}

\begin{abstract}
Abstrak
Tahapan Pencalonan Anggota DPR dan DPRD Provinsi dan DPRD Kabupaten/Kota dimulai dari pendaftaran dan verifikasi calon anggota DPR dan DPRD Provinsi dan DPRD Kabupaten/Kota.Adapun para bakal calon anggota legislatif yang telah dipilih oleh partai politik untuk didaftarkan sebagai calon anggota DPR dan DPRD perlu melengkapi syarat-syarat sebagaimana telah ditetapkan oleh Undangundang yang mana secara garis besarnya yaitu ada syarat calon dan syarat pencalonan. Dimana kedua syarat ini perlu didaftarkan oleh partai politik ke KPU sesuai dengan tingkatan nya. Namun, dalam melengkapi syarat-syarat, syarat calon dan syarat pencalonan ini ada indikasi terjadi keliru, dan perbuatan manipulasi syarat-syarat dan hal-hal lain yang dilakukan oleh Partai Politik pengusung maupun oleh bakal calon anggota legislatif ini untuk melengkapi syarat-syarat tersebut agar ditetapkan sebagai calon oleh KPU maupun KPUD.Pengumpulan data dilakukan dengan penelitian kepustakaan, observasi, dan wawancara.. Pendaftaran bakal calon anggota DPR dan DPRD Provinsi dan DPRD Kabupaten/Kota dilakukan oleh Partai Politik sesuai dengan tingkatan nya. Dalam rangkaian tahapan/proses pencalonan, ditemukan tindakan yang berkaitan dengan malpraktik pemilu atau pelanggaran pemilu, seperti pemalsuan/pengelabuan dokumen administrasi persyaratan calon maupun proses sengketa pemilu yang ditangani oleh badan pengawas pemilu (Bawaslu).lokus penelitian penulis adalah di kabupaten Solok, tepatnya di KPU Kabupaten Solok dikarenakan adanya kejanggalan-kejanggalan yang dilakukan oleh bakal calon dalam melengkapi syarat-syarat administrasi pencalonan.
\end{abstract}

Kata kunci:Pencalonan, Daftar Calon Sementara (DCS), Daftar Calon Tetap (DCT)

*Correspondence Address : vikodarmash@yahoo.com DOI : $10.31604 /$ jips.v6i2.2019.344-357

(C)2019 Fakultas Keguruan \& Ilmu Pendidikan UM-Tapanuli Selatan 


\section{PENDAHULUAN}

Pemilihan umum atau yang disingkat dengan pemilu telah menjadi bagian yang tidak dapat dipisahkan bagi negara-negara yang menganut sistem demokrasi yang memberikan manfaat kehidupan demokrasi, yaitu kekuasaan berada di tangan rakyat. Dalam suatu negara yang menganut sistem demokrasi, pemilu dijadikan sebagai momentum penting bagi pembentukan serta penyelenggaraan pemerintahan suatu negara. Bisa dikatakan bahwa selain sebagai mekanisme untuk memilih wakil-wakil rakyat, pemilu juga merupakan suatu proses evaluasi serta pembentukan kembali kontrak sosial.

Pemilupada hakikatnya adalah suatu proses sekaligus sarana demokrasi untuk menyalurkan pendapat rakyat dan juga merupakan suatu mekanisme yang dilakukan dalam memilih orang-orang yang nantinya akan mengisi berbagai jabatan politik tertentu, mulai dari jabatan presiden, wakil presiden, DPR, DPD, DPRD Provinsi, DPRD Kabupaten/Kota, Gubernur serta Walikota/Bupati. Selain itu pemilu juga merupakan proses perputaran pejabat yang bersifat inklusif dimana semua warga secara terbuka memiliki kesempatan untuk memilih dan dipilih. Melalui proses pemilu, masyarakat memiliki kesempatan untuk menentukan harapan, keinginan dan berbagai kepentingannya melalui pilihan-pilihan politiknya yang di salurkan dalam pemilu.

Melalui pemilu rakyat diberi hak sepenuhnya untuk menyalurkan aspirasi dalam penyelenggaran sebuah negara yang demokrasi. Pemilu merupakan salah satu mekanisme demokrasi di Negara Kesatuan Republik Indonesia(NKRI), seperti yang diamanatkan dalam Undang-undang Dasar 1945 Pasal 1 ayat 2, menyatakan bahwa "kedaulatan berada ditangan rakyat dan dilaksanakan berdasarkan undang undang. Pemilihan umum (pemilu) juga menjadi salah satu parameter bagi sebuah negara yang menjalankan prinsip-prinsip demokrasi.

Penyelenggaraan pemilu yang bersifat langsung, umum, bebas, jujur, adil dan akuntabel perlu didukung suatu lembaga yang kredibel sekaligus diikuti oleh peserta pemilu yang punya niat baik dalam menjalankan proses demokrasi sekaligus kontestasi pemilu secara jujur dan berintegritas. Untuk itu, lembaga penyelenggara pemilu harus mempunyai integritas yang tinggi, ketidakberpihakan kepada salah satu peserta pemilu serta memahami tugas 
dan tanggung jawab sebagai penyelenggara pemilu dan menghormati hak-hak politik dari warga negara.

Komisi pemilihan umum, adalah lembaga penyelenggara pemilu. KPU sebagai penyelenggara Pemilu dan sebagaimana diamanatkan dalam Undang-Undang Nomor 7 Tahun 2017 dalam menyelenggarakan Pemilu berkomitmen dan berpedoman pada azas mandiri, jujur, adil, tertib dalam menyelenggarakan pemilu, terbuka, profesional, efisien dan efektif mengingat tugas KPU adalah menyelenggarakan pemilu anggota Dewan Perwakilan Rakyat (DPR), anggota Dewan Perwakilan Daerah (DPD), anggota Dewan Perwakilan Rakyat Daerah (DPRD), serta pemilu Presiden dan Wakil Presiden yang diselenggarakan secara langsung oleh rakyat.

Komisi Pemilihan Umum kabupaten/kota, selanjutnya disingkat KPU Kabupaten/Kota, adalah penyelenggara pemilu yang bertugas melaksanakan pemilu di kabupaten/kota. Salah satu tahapan penyelenggaraan pemilu anggota legislatif adalah pendaftaran dan penetapan calon-calon anggota legislatif, khususnya calon anggota DPRD di Kabupaten/Kota, yang dalam penelitian ini adalah bakal calon anggota legislatif daerah Kabupaten Solok periode 20192024.

Berdasarkan hasil pengamatan awal di KPU Kabupaten Solok juga ditemukan bahwa dalam Pendaftaran calon anggota legislatif daerah (DPRD) Kabupaten Solok terindikasi bermasalah. Terjadi tarik ulur antara KPUD dengan beberapa partai politik peserta pemilu yang mengajukan namanama bakal calon anggota legislatif, khususnya bakal calon anggota DPRD Kabupaten Solok. Ada kelengkapan dokumen pendaftaran calon yang terindikasi pemalsuan, ada nama-nama bakal calon anggota DPRD Kabupaten Solok yang oleh KPU Kabupaten Solok dianggap belum memenuhi syarat administratif sehingga nama-nama mereka tidak lolos verifikasi administratif walaupun telah diberi kesempatan untuk melengkapi persyaratan, namun sampai pada batas waktu yang ditetapkan, belum terpenuhi, adanya tanggapan masyarakat terhadap nama-nama bakal calon yang telahditetapkan dalam Daftar Calon Sementara (DCS), dan adanya rekomendasi dan mediasi dari bawaslu Kabupaten Solok agar beberapa bakal calon anggota DPRD Kabupaten Solok untuk ditetapkan sebagai Calon dalam 
Daftar Calon Tetap, walaupun bakal calon tersebut tidak memenuhi/melengkapi persyaratan. Sehingga hal ini di indikasikan bahwa telah terjadi pelanggaran, malpraktik maupun manipulasi dalam proses pendaftaran calon anggota DPRD Kabupaten Solok.

\section{Kerangka Teori}

\section{Komisi Pemilihan Umum (KPU)}

Ketentuan yang melahirkan Komisi Pemilihan Umum (KPU) terdapat dalam pasal 22E Undang-undang Dasar Negara Republik Indonesia tahun 1945 dalam bab VII B pemilihan umum yang merupakan hasil perubahan ketiga Tahun 2001. Dalam Pasal 22E ayat (5) ini menyatakan bahwa, pemilihan umum diselenggarakan oleh suatu komisi pemilihan umum yang bersifat nasional, tetap dan mandiri.Dalam hal ini, nama komisi pemilihan umum belum menunjukkan nama yang pasti, namun hal ini menjadi dasar bahwa pemerintah terlepas dari KPU yang bertugas menyelenggarakan Pemilu sebagai organ yang mandiri di dalam menjalankan Tugas dan wewenangnya.

Menurut Asshiddiqie (2006:236239) Komisi Pemilihan Umum adalah lembaga negara yang menyelenggarakan pemilihan umum di Indonesia, yakni meliputi Pemilihan Umum Anggota DPR/DPD/DPRD, Pemilihan Umum Presiden dan Wakil Presiden, serta pemilihan umum Kepala Daerah dan Wakil Kepala Daerah. Komisi pemilihan umum tidak dapat disejajarkan kedudukannya dengan lembagalembaga negara yang lain yang kewenangannya ditentukan dan diberikan oleh UUD 1945.

Komisi Pemilihan Umum sebagai lembaga independen dalam sistem ketatanagaraan Indonesia mempunyai tugas, wewenang dan kewajiaban sebagai penyelanggara pemilu yang disebutkan dalam Undang-Undang Nomor 7 Tahun 2017 tentang Pemilu. Adapun tugas, wewenang, kewajiban, Komisi Pemilihan Umum menurut undang-undang ini ,yaitu:

1. Tugas dan wewenang Komisi Pemilihan Umum dalam penyelenggaraan Pemilu Anggota Dewan Perwakilan Rakyat (DPR), Dewan Perwakilan Daerah (DPD), dan Dewan Perwakilan Rakyat Daerah (DPRD).

2. Tugas dan wewenang Komisi Pemilihan Umum dalam penyelenggaraan Pemilu Presiden dan Wakil Presiden.

3. Tugas dan wewenang Komisi Pemilihan Umum dalam 
penyelenggaraan pemilihan gubernur, bupati, dan walikota.

\section{Pemilihan Umum}

Pemilihan Umum, menurut Tricahyo (2009:6) menyatakan pemilu adalah salah satu instrumen mewujudkan kedaulatan rakyat yang bermaksud membentuk pemerintahan yang sah serta sarana mengartikulasi aspirasi dan kepentingan rakyat. Sedangkan menurut Morissan (2005:17) pemilihan umum merupakan salah satu hak asasi warga negara yang sangat prinsipil sebagai perwujudan kedaulatan rakyat. Pemilihan umum adalah cara atau sarana untuk mengetahui keinginan rakyat mengenai arah dan kebijakan negara kedepan.

\section{Lembaga Legislatif}

Secara tradisional fungsi utama legislatif menetapkan kebijaksanaan umum, yang mengikat seluruh anggota masyarakat secara otoritatif. Mereka memiliki kekuatan dan bervariasi dari satu sistem politik ke sistem politik lain, untuk mengontrol badan-badan administratif, untuk memeriksa, memilih, mengubah, memutuskan, dan memberikan saran sesuai dengan masing kebijaksanaan umum dan juga melayani sebagai forum politik yang popular (Abcarian dan Masannant 1970:171).

\section{Pendaftaran}

Calon

Anggota DPR/DPRD

Salah

satu tahapan penyelenggaraan Pemilu Serentak Tahun 2019sebagaimana diatur dalam Peraturan KPU Nomor 5 Tahun 2018 Tentang Tahapan, Program dan Jadwal Penyelenggaran Pemilihan Umum Tahun 2019 adalah Pencalonan Anggota Dewan Perwakilan Rakyat (DPR), Dewan Perwakilan RakyatDaerah (DPRD) Provinsi dan Dewan Perwakilan RakyatDaerah(DPRD) Kabupaten/Kota. Tahapan Pencalonan Anggota DPR dan DPRD Provinsi dan DPRD Kabupaten/Kota dimulai dari pendaftaran dan verifikasi calon anggota DPR dan DPRD Provinsi dan DPRD Kabupaten/Kota. Pendaftaran bakal calon anggota DPR dan DPRD Provinsi dan DPRD Kabupaten/Kota dilakukan oleh Partai Politik sesuai dengan tingkatan nya.

Pencalonan anggota DPR, DPD, DPRD menurut undang-undang merupakan suatu proses atau rangkaian tahapan pendaftaran calon yang dimulai dari melengkapi berkas-berkas syarat calon maupun syarat pencalonan sebagaimanna yang telah diatur dalam 
Undang-Undang Nomor 7 Tahun 2017 tentang Pemilihan Umum dan Peraturan KPU Nomor 20 Tahun 2018 tentang Pencalonan Anggota DPR, DPRD Provinsi dan DPRD Kabupaten/Kota, selanjutnya tahapan verifikasi berkas calon yang dilaksanakan oleh KPU sesuai tingkatannya, penetapan daftar calon sementara (DCS), penerimaan tanggapan masyarakat terhadap DCS, masa perbaikan dan penggantian bakal calon, selanjunnya penetapan Daftar Calon Tetap (DCT).

\section{Pelanggaran/Malpraktik Pemilu}

Menurut Birch (2007: 1536), malpraktik pemilu adalah tindakan yang dilakukan kandidat (baik yang menjabat atau yang tidak) melakukan tekanantekanan pada tingkat penyelenggara. Lebih jauh, malpraktik pemilu menurut Birch mengandung 3 dimensi pelanggaran, yaitu manipulasi peraturan tatakelola pemilu, manipulasi preferensi suara dan manipulasi proses pemilihan. Oleh karena menyangkut manipulasi, maka pelaku malpraktik pemilu adalah orang-orang yang memang memiliki akses bagi terjadinya pelanggaran pemilu, sehingga malpraktik pemilu meyebabkan terjadinya penyimpangan dan pelanggaran dalam penyelenggaraan pemilu sehingga pemilu berjalan diluar prosedur atau tidak normal. Tidak tertutup kemungkinan terjadinya ketidaknormalan dalam proses pencalonan menyebabkan terganggunya integritas dan kualitas penyelenggaraan pemilu yang bisa saja disebabkan oleh penyelenggara (KPU dan Bawaslu) maupun oleh kandidat. Hal ini lah yang menarik perhatian bagi penulis untuk meneliti lebih jauh mengenai proses ini.

\section{Metode Penelitian}

\section{Jenis Penelitian}

Berdasarkan pada masalah yang penulis angkat dalam penelitian ini maka jenis Penelitian ini menggunakan bentuk deskriptif kualitatif yang memaparkan, menafsirkan dan menganalisis data yang ada. Penelitian kualitatif, menurut Moleong (2002:3), mendefinisikan Metodologi kualitatif sebagai prosedur penelitian yang menghasilkan data deskriptif berupa kata-kata tertulis atau lisan dari orangorang dan perilaku yang diamati.

\section{Fokus Penelitian}

1. Mengetahui dan menganalisis bagaimanakah proses pendaftaran calon pada tahapan pencalonan Anggota DPRD Kabupaten Solok untuk PemiluTahun 2019 . 
2. Mengetahui dan menganalisis bagaimanakah tindakan-tidakan malpraktik pemilu yang dilakukan oleh bakal calon anggota DPRD Kabupaten Solok untuk dapat lolos dari proses pendaftaran calon dan Peran Penyelenggara Pemilu (KPU dan Bawaslu Kabupaten Solok).

Hasil penelitian dari peneliti selanjutnya dibahas pada bab berikutnya dengan menelaah seluruh tahapan pencalonan dan dinamika yang terjadi selama pencalonan serta melihat aspek-aspek malpraktik pemilu yang terjadi selama proses pencalonan sampai dengan penetapan calon oleh KPU

\section{HASIL DAN PEMBAHASAN}

Kabupaten Solok adalah sebuah wilayah administratif dengan ibukota di Arosuka. Kabupaten Solok, sebuah wilayah pemerintahan di Propinsi Sumatera Barat yang terletak pada

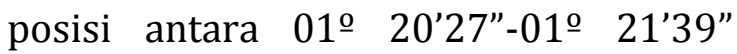
Lintang Selatan dan $100^{\circ} 2^{\prime} 00^{\prime}-100^{\circ}$ 33'43' Bujur Timur. Secara legal formal, Kabupaten Solok dibentuk berdasarkan Undang-undang Nomor 12 Tahun 1956 tentang Pembentukan Daerah Otonom Kabupaten dalam Lingkungan Daerah Propinsi Sumatera Tengah. Kabupaten Solok terdiri dari 14 Kecamatan yang mencakup di seluruh wilayah Kabupaten Solok.

Komisi Pemilihan Umum Kabupaten Solok Sebagai penyelenggara pemilihan umum ditingkat Kabupaten Solok, yang merupakan bagian dari hierarki penyelenggara pemilu ditingkat Kabupaten/Kota memiliki tugas dan wewenang sebagaimana diamanatkan dalam Undang-Undang Republik Indonesia Nomor 7 Tahun 2017 Tentang Pemilihan Umum.

KPU Kabupaten Solok telah menetapkan 4 (empat) daerah pemilihan (Dapil) dengan alokasi kursi sebanyak 35 kursi dengan rincian dapil berdasarkan kecamatan yaitu wilayah dapil satu yang terdiri dari Kecamatan X Koto Diatas, X koto Singkarak dan Junjuang Sirieh dengan 6 (enam) kursi. Kemudian dapil dua dengan wilayah kecamatan Gunung Talang, Kubung dan Kecamatan IX Koto Sungai Lasi dengan 11 (sebelas) kursi perwakilan di DPRD. Dapil tiga dengan wilayah Kecamatan Bukit Sundi, Payung Sekaki, Lembang Jaya, Danau Kembar dan Tigo Lurah dengan total 9 (sembilan) kursi. Lalu diikuti dengan dapil empat dengan wilayah kecamatan Hiliran Gumanti, Lembah Gumanti dan Pantai Cermin dengan 9 (sembilan) kursi. 
Masa pendaftaran bakal calon anggota legislatif (caleg) ke KPU telah berlangsung pada 4 hingga 17 Juli 2018. Komisi Pemilihan Umum (KPU) sudah menutup pendaftaran bakal calon anggota legislatif (caleg) untuk Pemilu 2019 pada 17 Juli lalu. Pengumuman daftar calon tetap dari 16 peserta pemilu dijadwaalkan pada 21- 23 September 2018. Akankah Republik ini akan memiliki lembaga legislatif yang berintegritas dan bobot profesionalitas yang baik. Berdasarkan tahapannya, KPU membuka pendaftaran calon anggota legislatif (caleg) untuk Pemilu 2019 sejak 4 Juli lalu dan berakhir 17 Juli. Berdasarkan Peraturan KPU (PKPU), partai politik (parpol) menyerahkan daftar bakal calegnya ke KPU di masing- masing tingkatan. Dari daftar bakal caleg ini diwajibkan terdapat $30 \%$ perwakilan perempuan. Bakal caleg harus memasukkan data lewat Sistem Informasi Calon (Silon) agar masyarakat bisa menilai danmemberi masukan. Tujuan lainnya, untuk mencegah tidak ada lagi bakal caleg ganda baik di parpol, daerah pilihanmaupun pada tingkatan dewan perwakilan.

Setelah proses pendaftaran, KPU melakukan tahapan verifikasi kelengkapan administrasi bakal calon dan menyampaikan hasilnya kepada partai politik peserta pemilu. Parpol diberi kesempatan perbaikan daftar calon dan syarat calon anggota serta pengajuan bakal calon pengganti pada 22-31 Juli 2018. Pengumuman daftar calon tetap dilakukan pada 21-23 September 2018. Sedangkan pemilihan legislatif (pileg) akan dilaksanakan serentak pada 17 April 2019 di seluruh Indonesia.

Komisi Pemilihan Umum (KPU) Kabupaten Solok, Sumatera Barat menyatakan sebanyak 76 caleg di daerah itu gagal dan tidak lolos masuk dalam daftar calon sementara (DCS). Komisioner KPU Kabupaten Solok, Defil di Koto Baru, menyebutkan caleg yang gagal masuk DCS itu dinyatakan tidak memenuhi syarat karena tidak melengkapi berkas-berkas persyaratan mereka seperti hasil pemeriksaan kesehatan dan surat dari pengadilan. akan tetapi saat masa perbaikan mereka tidak melakukan penggantian caleg maupun melakukan perbaikan berkas karena berbagai hal sehingga jumlah caleg yang gagal cukup banyak. Para caleg yang gagal itu berasal dari Partai Garuda dari semua dapil sebanyak 35 orang, Partai PKB dua dapil 26 orang, PSI enam orang dan PKPI di dapil IV sebanyak sembilan orang. 
Jadi, jumlah daftar caleg sementara (DCS) 459 orang, dengan laki-laki 295 orang, dan perempuan 164 orang dan telah di umumkan pada 12 hingga 14 Agustus 2018," katanya. Kemudian, dari 12 hingga 21 Agustus 2018, KPU menunggu masukan dan saran dari masyarakat mengenai Caleg yang diumumkan, jika ada laporan atau saran caleg memalsukan dokumen atau lainnya, caleg tersebut akan digugurkan. Pengumuman Daftar Calon Tetap (DCT) pada 21 September 2018. Menurut keterangan dari Komisioner KPU Kabupaten Solok, para caleg paling dominan bekerja sebagai pedagang, wiraswasta dan ada juga dari wali nagari, Badan Musyawarah Nagari (BMN), pensiunan polisi dan pensiunan pegawai.. Usia caleg berkisar dari 22 hingga 65 tahun, ada yang mahasiswa bahkan sudah mendaftar sebagai caleg. proses verifikasi ini dilakukan sebanyak tiga tahap. Yaitu kelengkapan dokumen pendaftaran, formulir pengajuan hingga kelengkapan syarat bacaleg. Adapun syarat-syarat pendaftaran calon anggota legislative ini adalah : Syarat bakal calon anggota DPR, DPRD provinsi dan DPRD kabupaten/kota berdasarkan Pasal 240 UU No 7 Tahun 2017 tentang Pemilu adalah Warga Negara Indonesia dan harus memenuhi persyaratan sebagai berikut:

- telah berumur 21 (dua puluh satu) tahun atau lebih;

- bertakwa kepada Tuhan Yang Maha Esa;

- bertempat tinggal di wilayah Negara Kesahran Republik Indonesia;

- dapat berbicara, membaca, dan/atau menulis dalam' bahasa Indonesia;

- berpendidikan paling rendah tamat sekolah menengah atas, madrasah aliyah, sekolah menengah kejuruan, madrasah aliyah kejuruan, atau sekolah lain yang sederajat;

- setia kepada Pancasila, UndangUndang Dasar Negara Republik Indonesia Tahun 1945, Negara Kesatuan Republik Indonesia, dan Bhinneka Tunggal Ika;

- tidak pernah dipidana penjara berdasarkan putusan pengadilan yang telah memperoleh kekuatan hukum tetap karena melakukan tindak pidana yang diancam dengan pidana penjara 5 (lima) tahun atau lebih, kecuali . secara terbuka dan jujur mengemukakan kepada publik 
bahwa yang bersangkutan mantan terpidana;

- sehat jasmani, rohani, dan bebas dari penyalahgunaan narkotika;

- terdaftar sebagai pemilih;

- bersedia bekerja penuh waktu;

- mengundurkan diri sebagai kepala daerah, wakil kepala daerah, aparahrr sipil negara, anggota Tentara Nasional Indonesia, anggota Kepolisian Negara Republik Indonesia, direksi, komisaris, dewan pengawas dan karyawan pada badan usaha milik negara dan/atau badan usaha milik daerah, atau badan lain yang anggarannya bersumber dari keuangan negara, yang dinyatakan dengan surat pengunduran diri yang tidak dapat ditarik kembali;

- bersedia untuk tidak berpraktik sebagai akuntan publik, advokat, notaris, pejabat pembuat akta tanah, atau tidak' melakukan pekerjaan penyedia barang dan jasa yang berhubungan dengan keuangan negara serta pekerjaan lain yang dapat menimbulkan konflik kepentingan dengan tugas, wewenang, dan hak sebagai anggota DPR, DPRD provinsi, dan DPRD kabupaten/kota sesuai dengan ketentuan peraturan perundangundangan;

- bersedia untuk tidak merangkap jabatan sebagai pejabat negara lainnya, direksi, komisaris, dewan pengawas dan pada badan usaha milik negara dan/atau badan usaha milik daerah serta badan Lain yang anggarannya bersumber dari keuangan negara;

- menjadi anggota Partai Politik Peserta Pemilu;

- dicalonkan hanya di I (satu) lembaga perwakilan dan

- dicalonkan hanya di 1 (satu) daerah pemilihan.

Syarat-syarat calon legislatif tersebut diatas disertasi dengan kelengkapan administratif sebagaimana disebutkan dalam Pasal 240 ayat (2) UU No 7 Tahun 2017

$$
\text { Selanjutnya KPU juga }
$$

menerbitkan peraturan turunan dari pendaftaran calon ini, KPU menerbitkan Peraturan Nomor 20 Tahun 2018 tentang Pencalonan Anggota DPR, DPRD, dan DPRD. Peraturan ini mengatur seabrek syarat bagi waga yang ingin jadi calon anggota DPR atau DPRD di Pemilu 2019. Perubahan paling mencolok dari 
peraturan ini adalah dilaranganya mantan terpidana korupsi, bandar narkoba, dan predator seksual menjadi caleg. "Bukan mantan terpidana bandar narkoba, kejahatan seksual terhadap anak, atau korupsi," bunyi peraturan KPU pasal 7 ayat 1, huruf h. ketentuan lengkap menjadi caleg di Pemilu 2019:

(1) Bakal calon anggota DPR, DPRD Provinsi, dan DPRD Kabupaten/Kota adalah Warga Negara Indonesia dan harus memenuhi persyaratan:

a) telah berumur 21 (dua puluh satu) tahun atau lebih terhitung sejak penetapan DCT

b) bertakwa kepada Tuhan Yang Maha Esa

c) bertempat tinggal di wilayah Negara Kesatuan Republik Indonesia

d) dapat berbicara, membaca, dan/atau menulis dalam bahasa Indonesia

e) berpendidikan paling rendah tamat sekolah menengah atas, madrasah aliyah, sekolah menengah kejuruan, madrasah aliyah kejuruan, atau sekolah lain yang sederajat

f) setia kepada Pancasila, UndangUndang Dasar Negara Republik Indonesia Tahun 1945, Negara
Kesatuan Republik Indonesia, dan Bhinneka Tunggal Ika

g) tidak pernah sebagai terpidana berdasarkan putusan pengadilan yang telah memperoleh kekuatan hukum tetap yang diancam dengan pidana penjara 5 (lima) tahun atau lebih berdasarkan putusan pengadilan yang telah berkekuatan hukum tetap

h) bukan mantan terpidana bandar narkoba, kejahatan seksual terhadap anak, atau korupsi

i) sehat jasmani, rohani, dan bebas penyalahgunaan narkotika, psikotropika dan zat adiktif

j) terdaftar sebagai pemilih

k) bersedia bekerja penuh waktu

l) mengundurkan diri sebagai:

1. gubernur, wakil gubernur, bupati, wakil bupati, wali kota atau wakil wali kota

2. kepala desa

3. perangkat desa yang mencakup unsur staf yang membantu Kepala Desa dalam penyusunan kebijakan dan koordinasi yang diwadahi dalam Sekretariat Desa, dan unsur pendukung tugas Kepala Desa dalam pelaksanaan kebijakan yang diwadahi dalam bentuk 
pelaksana teknis dan unsur kewilayahan

4. Aparatur Sipil Negara

5. anggota Tentara Nasional Indonesia

6. anggota Kepolisian Negara Republik Indonesia

7. direksi, komisaris, dewan pengawas dan/atau karyawan pada Badan Usaha Milik Negara, Badan Usaha Milik Daerah, Badan Usaha Milik Desa, atau badan lain yang anggarannya bersumber dari keuangan negara

8. mengundurkan diri sebagai Penyelenggara Pemilu, Panitia Pemilu, atau Panitia Pengawas

9. bersedia untuk tidak berpraktik sebagai akuntan publik, advokat, notaris, pejabat pembuat akta tanah, atau tidak melakukan pekerjaan penyedia barang dan jasa yang berhubungan dengan keuangan negara serta pekerjaan lain yang dapat menimbulkan konflik kepentingan dengan tugas, wewenang, dan hak sebagai anggota DPR, DPRD Provinsi, dan DPRD Kabupaten/Kota sesuai dengan ketentuan peraturan perundangundangan

10. bersedia untuk tidak merangkap jabatan sebagai pejabat negara lainnya, direksi, komisaris, dewan pengawas dan/atau karyawan pada Badan Usaha Milik Negara, Badan Usaha Milik Daerah, Badan Usaha Milik Desa, atau badan lain yang anggarannya bersumber dari keuangan negara;

11. menjadi anggota partai politik.

12. dicalonkan hanya di 1 (satu) lembaga perwakilan

13. dicalonkan hanya oleh 1 (satu) partai politik

14. dicalonkan hanya di 1 (satu) Dapil; dan

15. mengundurkan diri sebagai anggota DPR, DPRD Provinsi, atau DPRD Kabupaten/Kota bagi calon anggota DPR, DPRD Provinsi, atau DPRD Kabupaten/Kota yang dicalonkan oleh Partai Politik yang berbeda dengan Partai 
Politik yang diwakili pada Pemilu Terakhir.

\section{KESIMPULAN}

Bahwa, proses pendaftaran calon anggota DPRD juga memunculkan beberapa polemik dan dinamika yang bisa menyebabkan terjadinya malpraktik pemilu yang dilakukan oleh kandidat untuk memuluskan tujuan nya. Bagi bacaleg yang didaftarkan oleh partai politik sesuai tingkatan nya, proses pendaftaran calon ini memunculkan temuan kepada peneliti bahwa, banyak partai politik yang tidak siap dalam menghadapi proses ini, hal ini dibuktikan dengan kesulitan bacaleg dalam melengkapi bahan-bahan adminstratif yang merupakan sebagai suatu syarat pokok yang harus dipenuhi dalam proses pendaftaran calon, seperti, ijazah yang tidak dilegalisir, manipulasi dalam melengkapi bahan SKCK, Surat keterangan tidak pernah dipidana penjara dari Pengadilan, tidak cukup umur dan kewajiban mengundurkan diri sebagai kepala daerah, wakil kepala daerah, aparahrr sipil negara, anggota Tentara Nasional Indonesia, anggota Kepolisian Negara Republik Indonesia, direksi, komisaris, dewan pengawas dan karyawan pada badan usaha milik negara dan/atau badan usaha milik daerah, atau badan lain yang anggarannya bersumber dari keuangan negara, yang dinyatakan dengan surat pengunduran diri yang tidak dapat ditarik kembali.

Jika pemilu diibaratkan sebagai bangunan demokrasi, maka semestinya integritasnya adalah merupakan prasyarat kompetisi di semua tingkatan. Dalam sejumlah evaluasi yang dinyatakan sebagai praktik "miskin kejurdilan pemilu" selalu ditemukan bahwa warga begitu sadar akan kinerja buruk dan dikompromikannya secara jahat hasil-hasil setiap pemilihan. karena itu penting semakin disadari peran studi kepercayaan pemilu sebagai kunci untuk memahami keniscayaan demokrasi di dunia yang semakin kompetitif. Studi persepsi kejurdilan dan integritas pemilu tidak saja penting untuk pemilih, karena analisis serupa sangat menguntungkan jika dapat diperluas ke berbagai aspek perilaku politik. Melakukan tugas seperti itu akan memberikan kontribusi yang sangat dibutuhkan melawan manipulasi pemilu dan malpraktik yang dilembagakan secara jahat.

\section{Daftar Pustaka}

Afrizal (2014). Metode Penelitian Kualitatif: Sebuah Upaya Mendukung Penggunaan Penelitian Kualitatif Dalam Berbagai Disiplin Ilmu.Jakarta: PT Raja Grafindo Persada 
Almond dan Verba, 1984 Budaya Politik Tingkah Laku Politik, Bina Aksara, Jakarta.

Jimly Asshidiqie (2006), Perkembangan dan Konsolidasi Lembaga Negara pascaReformasi,Jakarta: Setjen dan Kepaniteraan MKRI

Ramlan Surbakti (1992), Memahami Ilmu Politik, Jakarta: PT Gramedia Widiasarana

Firmanzah. (2008). Marketing Politik Antara Pemahaman dan Realita. Jakarta: yayasan Pustaka Obor Indonesia

Arikunto, Suharsimi, 2010, Prosedur Penelitian: Suatu Pendekatan Praktik. PT Rineka Cipta, Jakarta Sugiono, 2010, Metode Penelitian Administrasi, CV.Alfabeta, Bandung

Eriyanto, 2007, Teknik Sampling, LkiS Yogyakarta. Hlm 166-167

Gaffar,Afan,1992,Javanese Voters: A Case Study of Elections Under a Hegemonic Party, Gadjah Mada University Press, Yogyakarta.

Ramlan Surbakti., 1992, Memahami Ilmu Politik. Grasindo, Jakarta.

Riduwan,DR, 2009, Metode dan teknik menyusun proposal penelitian,Alfabeta.

Sugiono, 2010, Metode Penelitian Administrasi, CV.Alfabeta, Bandung

Undang-Undang Nomor 2 Tahun 2008 Tentang Partai Politik

Undang-Undang Nomor 7 Tahun 2017 Tentang Pemilhan Umum

Peraturan Komisi Pemilihan Umum Nomor 5 Tahun 2018 Tentang Tahapan, Program dan Jadwal Penyelenggaran Pemilihan Umum Tahun 2019;
Peraturan Komisi Pemilihan Umum Nomor 20 Tahun 2018 Tentang Pencalonan Anggota DPR, DPRD Provinsi dan DPRD Kabupaten/Kota 